\title{
TWO MIDDLE KINGDOM STELAE OF SA AMUN AND SNEFRUIPTAH IN THE GREAT EGYPTIAN MUSEUM GIZA (CGC 20188=20686).
}

\author{
Adel Zine Al-Abedine \\ Department of Archeology \\ Faculty of Arts \\ University of Tanta
}

\author{
Nahla Fahim EL-Sayed \\ $\mathrm{PhD}$ in Egyptology
}

\begin{abstract}
The aim of this paper is to publish and study Two Abydos stelae preserved now in the Magazine of the Middle Kingdom in the Great Museum in Giza under the numbers (CGC 20188and 20686) with discussion of the meaning of their Names and titles. Furthermore, it aims to transcribe. Translate and comment on their epigraphical features. The first stela belongs to a person named Sa-Amun, while the second is a stela of Snefruiptah, the artistic style. The orthographic and paleographic features suggest a dating to the Late Twelfth Dynasty and early Thirteenth Dynasty, while of Snefruiptah is typical of the reign Senwosert III.
\end{abstract}

\section{KEYWORDS}

Middle Kingdom, false door stela. Sa-Amun, Snefruiptah, Senwosert III. Late Twelfth Dynasty. Early Thirteenth Dynasty.

\section{INTRODUCTION}

This paper is to publish and study funerary two stelae ${ }^{\mathrm{i}}$ preserved now in the store of the Middle Kingdom in the Great Egyptian Museum in Giza, the first one is a stela in the shape of a false door of person named Sa-Amun (CGC20188), the second is a false door stela of a person named Snefruiptah(CGC20686), The genealogy of the owners of the stelae are not mentioned on these

stelae, they were found at kom es-sultan ${ }^{\text {ii }}$ in Abydos, Sohag governorate, The stelae are in good condition, The current condition of the stelae in comparison with the black and white photographs taken at the time of its discovery shows no change, the stelae share shape and orthographical and paleographical features, when they are compared to each other, suggest for a single or close period, where the art of the end Twelfth Dynasty continues through the Thirteenth Dynasty. Both Lange and Schäfer ${ }^{\mathrm{iii}}$ transcribed the hieroglyphs of thses two stelae and included their images, but they did not translate their texts, describe their scenes, nor investigate their styles or inscriptions. The aim of this paper is to translate and comment thses documents, by investigating their style, inscriptions as well as their iconographica, epigraphical features and dating criteria. 


\section{1- The False Door Stela of Sa-Amun (fig.1)}

\section{General Description}

Rectangular stela in the shape of a false-door ${ }^{\text {iv }}$ of Sa-Amun, The stela is in a good of preservation, The genealogy of the owner of the stela is not mentioned on this stela, It is made of limestone, measuring $46.1 \mathrm{~cm}$ in height, $6.5 \mathrm{~cm}$ in width and $28 \mathrm{~cm}$ in length, Now, it is registered under the accession numbers (CG 20188=GEM 14248=SR 3/9422). The stela was found at kom es-sultan in Abydos, Sohag governorate (fig.1). It is in good condition, The current condition of the stela in comparison with the black and white photographs taken at the time of its discovery shows no change.

Rectangular stela in the shape of a false-door, it has fine relief scenes and hieroglyphic in scriptions, both of which are executed in sunked relief, It is of a rather simple design, It is topped by the winged sun-disk. It is divided vertically by a rectangular hole/niche ${ }^{\mathrm{v}}(32.5 \mathrm{~cm} \times 6.5 \mathrm{~cm})$. The god Osiris is depicted in the left side, while the god Min-Hor is depicted in the right side. The lower part inscribed by four horizontal lines of hieroglyphic inscriptions down every god in every side.

\section{Scenes and Inscriptions}

I-The top of the stela: As noted above, the upper section is decorated with the winged sun-disk ${ }^{\mathrm{vi}}$ surrounded by two cobras ${ }^{\text {vii }}$ around sun disk every side.

\section{II-Scenes}

In the left side of the false door stela, the god Osiris ${ }^{\text {viii }}$ is shown as a mummiform figure, he wears the white crown of Upper Egypt, suggests an upper Egyptian origin for the god, he wears the divine beard and the wide necklace, and he holds the wide scepter in both hands ${ }^{\mathrm{ix}}$.

In the right side of the false door stela, Min Hor Nekhet ${ }^{\mathrm{x}}$ appears in his traditional form as a human figure standing upright and wrapped as a mummy on the base with a slanted façade represented the maat, and his erect penis member, as the usury of fertility and sexual power ${ }^{\mathrm{xi}^{3}}$, his left arm is hidden in the scrolls, and his right arm $^{\text {xii }}$, it is represented lifted to head level with his elbow and forearm forming a right angle, while the palm of his hand is open. Above the hand is a flail $n h 3 h 3{ }^{\text {xiii }}$ hanging loose, he wears the distinctive crown (a double crown of feathers), the crown is tall and double plumed with a long ribbon in the back, Behind him the vessel, perhaps, is this vessel in which the lecttuce plant was placed, the symbol of the god Min or the shrine of $\operatorname{Min}^{\mathrm{xiv}}$.

\section{III-Inscriptions}

The main inscription on this stela contains four horizontal lines every side divided by incised horizontal lines, running right to left, the text contains on the offering formula, one of them was presented to the god Osiris, and the other is for the god Min Hor Nekhet, the text also contains the owner's name and his title, the first text down the god Osiris, contains four horizontal line, running right to left, as follows:

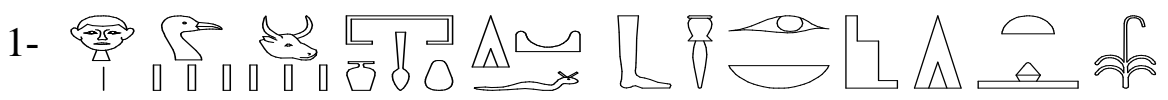


$-r$

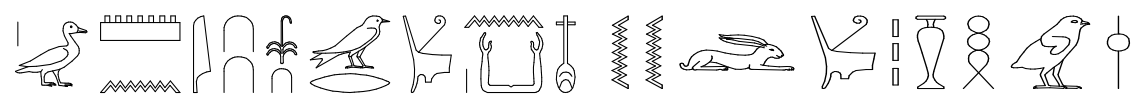

1- htp-di-nsw ${ }^{\mathrm{a}} w \operatorname{sir}^{\mathrm{b}} n b 3 b \underline{d} w^{\mathrm{c}}-d i \cdot f^{d} p r t-h r w^{h v} t h n k t k 3 w 3 p d w^{\mathrm{e}} h r$ 2- wdhw $n$ wnn4- nfr ${ }^{\mathrm{xvi}} n k 3 n^{\mathrm{f}} w r m \underline{d} w m \check{s}^{\complement} w^{\mathrm{g}} s 3 i m n^{h v i i}$

1-An offering which the king gives ${ }^{\mathrm{xviii}}$ (to) Osiris, lord of $\operatorname{Abydos}^{\mathrm{xix}}$, may he give ${ }^{\mathrm{xx}}$ invocation- offerings (consisting of ) bread and bear, oxen and fowl ${ }^{\mathrm{xxi}}$, 2- water pouring for wenen- nefer, to the ka of the Great of the Tens of Upper Egypt $^{\text {xxii }}$, Sa Amun.

The second text down the god Min Hor Nekhet, contains four horizontal line, running right to left, as follows:

$-1$

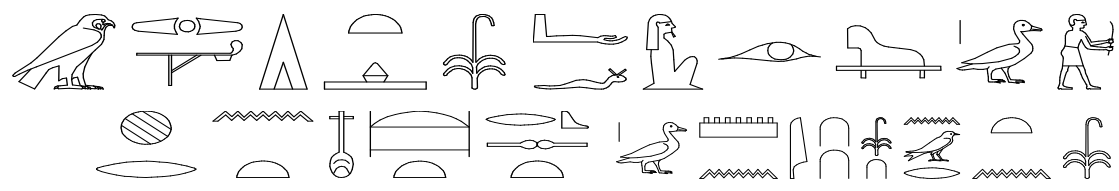

1- htp-di-nsw Mnw hrr nht ${ }^{\mathrm{h}}$ s3 wsir ${ }^{\mathrm{b}}$ di.f.hhiii

2- krstt nfr $n t$ hr nsw $n$ wr $m \underline{d} w$ w $m \varsigma^{\complement} w$ s3-imn

1- A boon which the king gives (to) Min Hor Nekhet, son Osiris, may he give

2- the beautiful tomb with the king for the Great of the Tens of Upper Egypt, Sa Amun.

\section{IV-Comment on the text:}

a) htp di $n s w{ }^{\text {xxiv }}$ : Offering formula appeared since the era of the fourth dynasty ${ }^{\mathrm{xxv}}$, The phonetic writing of the htp di nsw formula on our stela confirms its reading. That form of writing was attested from the Eleventh dynasty until the Thirteenth dynasty ${ }^{\mathrm{xxvi}}$.

b) wsir: This writing of the htp di nsw formula is the most common found on the monuments of the Middle Kingdom,Osiris name is written without a determinative ${ }^{\mathrm{xxvii}}$. And in the late end of the Twelfth Dynasty, the name of Osiris is written using the hieroglyphic sign Q2 instead of sign Q1 ${ }^{\text {xxviii }}$, This sign was first attested under Senosert III $^{\text {xxix }}$ and it was in use during the Thirteenth Dynasty ${ }^{\mathrm{xx}}$.

${ }^{c} N b 3 b \underline{d} w$ : the normal form of this title is without the determinative niwt, this form widely appears in the Thirteenth Dynasty on the stele of $i r$-gmt.f, stele of $s n b i^{\text {hhhiii }}$, In the New Kingdom, sometimes it appears with more abbreviation $\simeq$ xxxiv.

d) di.f : There is a new element to be observed in the offering formula of the early Middle Kingdom with the introduction of di.f, The use of di.f (may he give ) appeared during the 
Twelfth Dynasty ${ }^{\mathrm{xxx}}$, the only structural difference between Old Kingdom and Middle Kingdom formulas is the additional insertion of a prospective di.f "may he give", introducing the following request for an invocation offering ${ }^{\mathrm{xxxvi}}$, It is belived that prt-hrw was introduced during the Eleventh Dynasty, However, The construction changed in the Twelfth Dynasty to di.f/.s/.sn ${ }^{\text {hh }}$ vii .

e) $k 3 w-3 p d w$ : Oxen and fowl is one of the most ubiquitous elements of the offering formula, Secon It wrote this way on a few stelae of Twelfth Dynasty and Thirteenth Dynasty, spread the Second Intermediate Period ${ }^{\text {xxxviii }}$.

f) $n-k 3-n$ : The occurrence of this phrase on stela is probably known from an earlier date despite claims by Bennett ${ }^{\mathrm{xxxix}}$, although only later in the Dynasty did it make its way to the superstructure $^{\mathrm{xl}}$. Its occurrence on Stela is even later than the end of the Old Kingdom ${ }^{\mathrm{xli}}$.Bennett suggests that $n k 3 n$ occurred since the time of "Amenemhat II", after the alternations happened to the formula since the time of "Senusert I"xlii. This form of writing did not occur before the Thirteenth Dynasty ${ }^{\text {xliii }}$, All the inscriptions dating to the Thirteenth dynasty use the form $n-k 3-n$ $\mathrm{NN}$ xliv ,"to the ka of NN" to introduce the recipient ${ }^{x l v}$. And followed $n-k 3-n$ the name (and Titles) of the deceased to follow as well as one, or both ${ }^{\text {xlvi }}$.

g) $W r m \underline{d} w \breve{s} m^{\varsigma} w$ was evidently of great importance of high-ranking status, this is evident from the title he held ${ }^{\text {xlvii }}$, It was one of the most common regular titles of the late middle kingdom, A holder of this title was perhaps the staff of the vizier and officials in his bureau in the late middle kingdom and

h) $m n w$ hr-nht : appears in the offering formulas primarily in the Thirteenth Dynasty ${ }^{\text {xlviii }}$. the appearance of this god in the offering formula seems to be synchronous with the appearance of ithyphallic Min figures on Abydene stelae ${ }^{\text {xlix }}$, This god is attested in 10 Thirteenth Dynasty documents(docs.109, 139, 154, 155, 162, 164, 168, 170,191, 201) ${ }^{1}$.

Especially in Thirteenth Dynasty ${ }^{\mathrm{li}}$, Anyway, according to him, the monuments of the late middle kingdom attest the regular use of the title might in front of the owner's name ${ }^{\text {lii }}$.

\section{V-Dating of the Stela}

The offering formula permits us to propose the Late Twelfth Dynasty as a date for this stela. The absence of Osiris determinative is characteristic for the Late Twelfth Dynasty stela and later liii, and use the sign Q2 in the name of Osiris refers to the Thirteenth Dynasty, where it was used during the Thirteenth Dynasty ${ }^{\text {liv }}$.

The grammatical structure di.f prt-hrw is a chronological element of the stela of the Twelfth Dynasty and later ${ }^{1 v}$. The use of the sign $b^{3}(\mathrm{~S} 3)$ instead of the sign ${ }^{\text {mme }}$ (N35) in the formula $n-k 3-$ $n$, whether wrote Twelfth Dynasty ${ }^{\text {lvi }}$, then it became used on all stelae dating from the Thirteenth Dynasty ${ }^{\text {lvii }}$.

Depicting deities in large size on the body of the stela, such as Osiris ,Min, and Hor Ra Akhty, spread in the Thirteenth Dynasty, The phrase Mnw-hr-Nht in the offering formula outside the cultic centers of Min is a sign of a Thirteenth Dynasty date $e^{\text {Iviii }}$.

The shape of the stela is an important element of the history of the stela, as the rectangular stela appeared in the form an false door since the reign of the king Senwosert III and spread in the Thirteenth Dynasty ${ }^{\text {lix }}$.

The representations of winged sun disk in the top of this stela indicate a post to end Twelfth Dynasty date, the winged sun disk appeared surrounded by two snakes on a small number of the 
Middle Kingdom stelae, and the first appearance of the winged sun disk surrounded by two snakes was on the stela of a minister from the end of reign of the king senwosert I,then it appeared to be used by the public as a decorative element at the top of the stela since the end Twelfth Dynasty and later ${ }^{1 \mathrm{x}}$. One of the important elements in the history of this stela is the title $W r m \underline{d} w \check{s}^{\top} w$ was one of the most common regular titles of the Late Middle Kingdom, and continued in the Thirteenth Dynasty ${ }^{1 x i}$.

According to the abovementioned suggestions, this false-door stela could be dated back to the Late Twelfth Dynasty Early and Thirteenth Dynasty.

\section{2- The False Door Stela of Snefruiptah (fig.2)}

\section{Description and texts}

Rectangular stela in the shape of a false-door of Snefruiptah, The stela is in a good of preservation, The genealogy of the owner of the stela is not mentioned on this stela, It is made of limestone, measuring $47.5 \mathrm{~cm}$ in height, $9.5 \mathrm{~cm}$ in width and 25.5 in length, Now, it is registered under the accession numbers (CG 20686=JE 18525=GEM 4109=SR 3/10395). The stela was found in Abydos, Sohag governorate (fig.2). It is in good condition, the current condition of the stela in comparison with the black and white photographs taken at the time of its discovery shows no change, Imitating a false door, this stela designed like a façade of a temple, is framed by a cavetto cornice at the top and torus moulding on both sides ${ }^{\text {lxii }}$. According to Pflüger, this type first appeared during the reign of the king Amenemhat $\mathrm{I}^{\text {lxiii }}$. The stela is divided into three sections: the first consists of a cavetto cornice; the second is occupied by the main texts of the

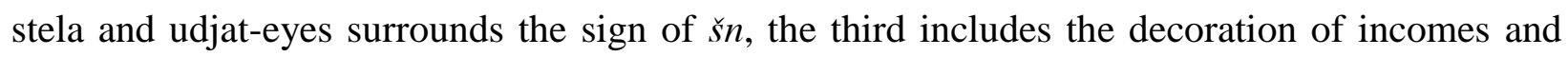
exits .

I- At the top of the stela is decorated with ancient Egyptian cavetto cornice, and of it there is a horizontal line of hieroglyphic inscriptions written from right to left, line reads :

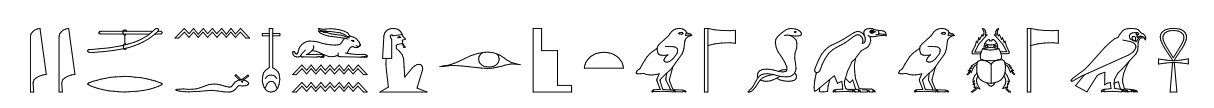

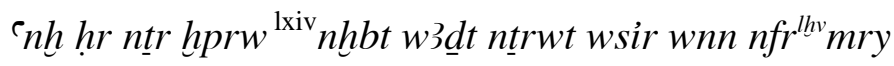

Live Horus, god shape, $n h b t w 3 \underline{d} t$ doddess, Osiris wen nefer beloved .

II- the second section (body of the stela), it is rectangular in shape, it is divided vertically by a rectangular hole, and begins with a horizontal hieroglyphic line, and line reads:
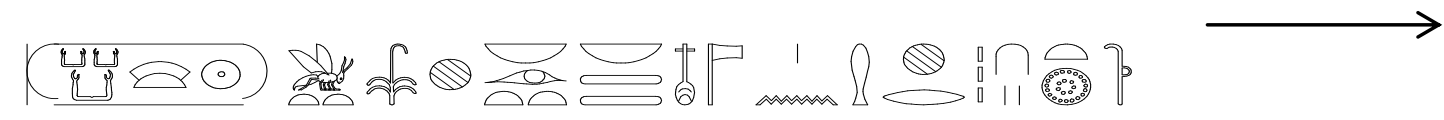

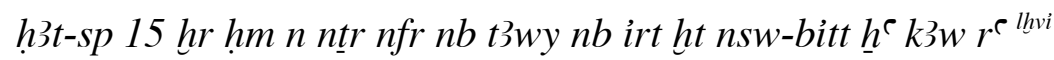

Year 15 under majesty the good god, lord of the two lands, lord of offering, king of upper and lower Egypt $\underline{h}^{\complement} k 3 w r^{\complement}$.

Below this line, there are udjat-eyes" $w d \underline{d} t^{\prime \prime x v i i}$ are incised which gaze at the observer, They symbolize the connection between the deceased and our world. A sign of round cartouch 
shen"šn"llhiiii is placed between the two eyes to confirm the protection, besides the udjat-eyes from the north side, there are two hieroglyphic signs above each other ${ }^{t} \Delta d i{ }^{\top} n h$.

In the left side of this section, there are the inscription of three vertical hieroglyphic lines running from right to left, text reads:

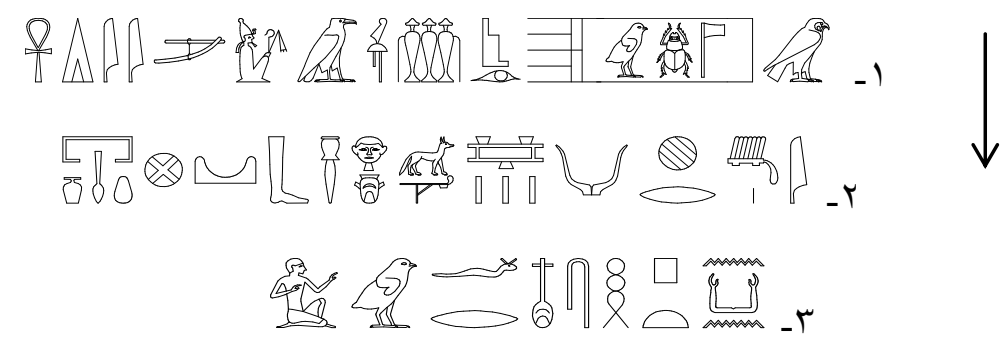

1- hr ntr hoprw wsir hnty imntyw ${ }^{\text {lhih }}$ mry di `nh $^{\text {h }}$

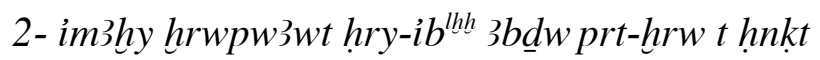

3-n-k3-n snfr.wi-pth $h^{\text {lhhi }}$

Horus ntr hprw, Osiris foremost of the westerners beloved given life, the venerated before Wepwawet ${ }^{\text {lxxii }}$ guest Abydos, invocation offering (consisting of) bread and bear, to the ka of Snefruiptah.

In the right side of this section, there are the inscription of three vertical hieroglyphic lines running from left to right, text reads:

1
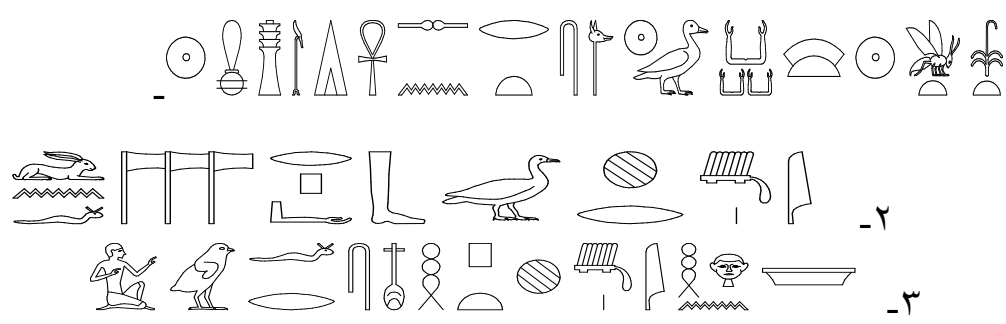

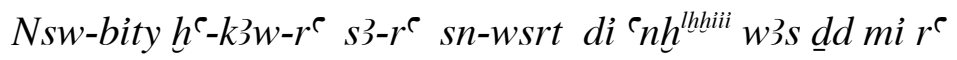

im3hy hr gb r-p`t ntrww wn.f wn hrr n im3hhy snfr.wilhhiv -pth

king of upper and lower Egypt $h^{c}-k 3 w-r^{c}$ son of Re Snwosert given life dominion and stable like $\mathrm{Re}$, the venerated before Geb , the noble, shining of gods to the venerated Snefruiptah .

III- The Third section includes the decoration of incomes and exits. On the left at the beginning of the third section, there is a horizontal hieroglyphic line, running from right to left, line reads:

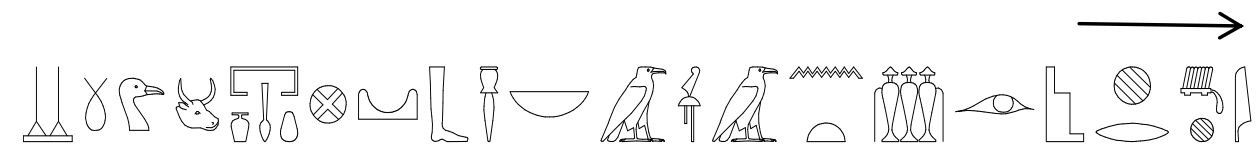

im3h(y) hr wsir hnty imntyw nb 3bdw prt-hrw k3w 3pdw šs mnht

The venerated before Osiris foremost of the westerners, lord of Abydos, invocation offerings (consisting of) bread and bear, cattle and fowl, alabaster and clothing . 
Below this, there are number of texts horizontal hieroglyphic lines running from right to left, begins on the right, text read:

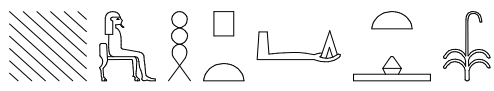

htp-di-nsw pth̆ šs

An offering which the king gives (to) ptah noble .

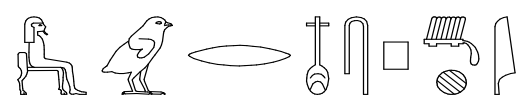

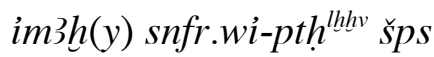

The venerated Snefruiptah noble.

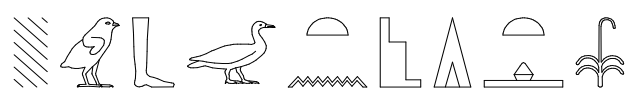

htp-di-nsw wsir $n$ gb.w ${ }^{l h h v i} \ldots$

An offering which the king gives (to) Osiris for Gebw.

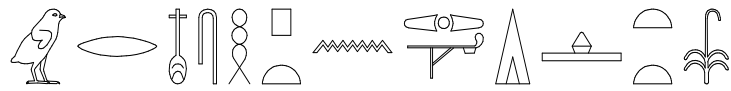

htp-di-nsw min n snfr.wi-ḥtp $p^{\text {lhhvii }}$

An offering which the king gives (to) for Snefruiptah .

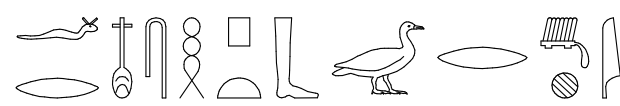

im3h(y) (h)r gb snfr.wi pth

the venerated before Geb Snefruiptah .

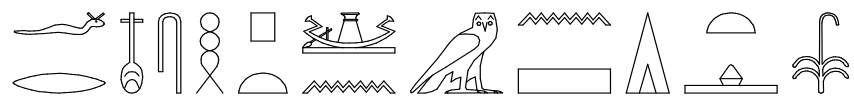

htp-di-nsw nšmt snfr.wi-ḥtp

An offering which the king gives (to) sacred barque of Osiris ${ }^{\text {lxxviii }}$ for Snefruiptah .

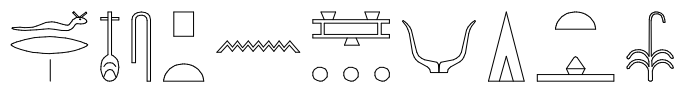

htp-di-nsw wp-w3wt n snfr.wi-htp ${ }^{\text {lhhil }}$

An offering which the king gives (to) wepwawet for Snefruiptah .

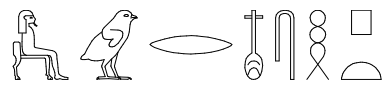

snfr.wi-pth šps

Snefruiptah noble.

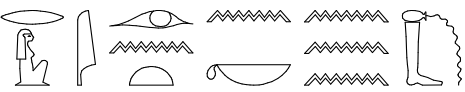


$w^{c} b$ n.k iry $n t$ iry ${ }^{\text {lhhh }}$

Cleanse for you iry nt iry

\section{IV-Dating of the Stela}

Date of The Stela back to the fifteenth year of the reign of king Senwosert III, Twelfth Dynasty. found three titles on the stela belonging to king Senwosert III; title Hory " ntr hprw",title nsw bity " $h^{\top} k 3 w r$ " " and title $s 3-r^{e}$ "sn-wsrt".

The stela included a number of features that were widespread in this period, The shape of the stela is an important element for this period, as the rectangular stelae with cornice and rounded

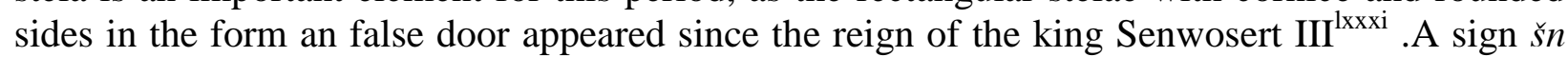
appeared surrounded by two eyes $w \underline{d} 3 t$ at the tops of the stelae since the reign of the king Senwosert III lxxxii. the order of the offering formula $h t p-d i-n s w$ with the sign of $h t p$ in the middle between $n s w$ and $d i^{\text {lxxxiii }}$, and the arrangement of $h t p-d i-n s w$ with the ${ }^{\bullet} t$ sign centered above the

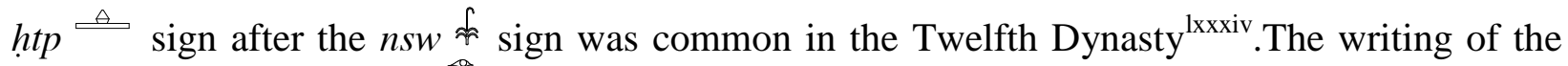
name of the god Osiris $\widehat{\vec{k}}$ without a determinative commonly occurs during the reign of Amenemhat III and lasted through the twelfth dynasty ${ }^{\operatorname{lxxv}}$. the abbreviated writing of the sign

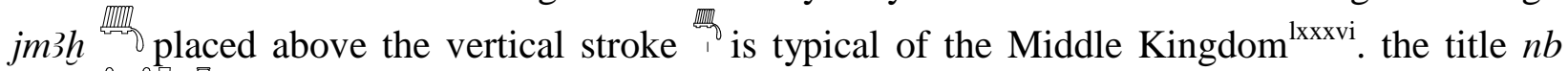
$3 b d w\left[\pi\right.$ with this form widely appears in the Twelfth Dynasty ${ }^{\text {lxxxvii }}$. The phrase $k 3 w$ $3 p d w$ \& 3 wrote this way during the Twelfth Dynasty ${ }^{1 \mathrm{xxxviii}}$.

\section{Figuration:}




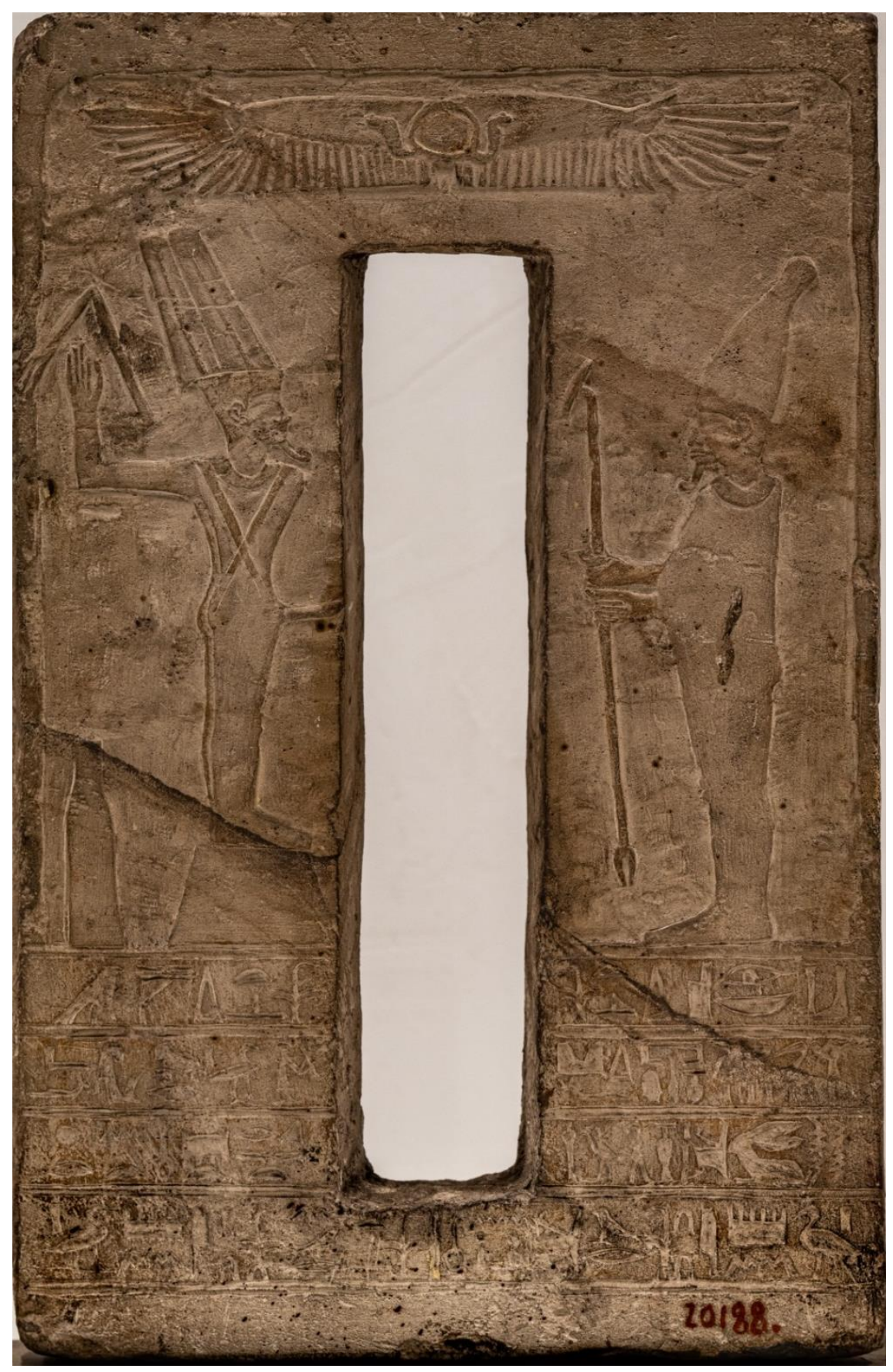

(fig. 1)

(CG20188-GEM 14248-SR 3/9422) 


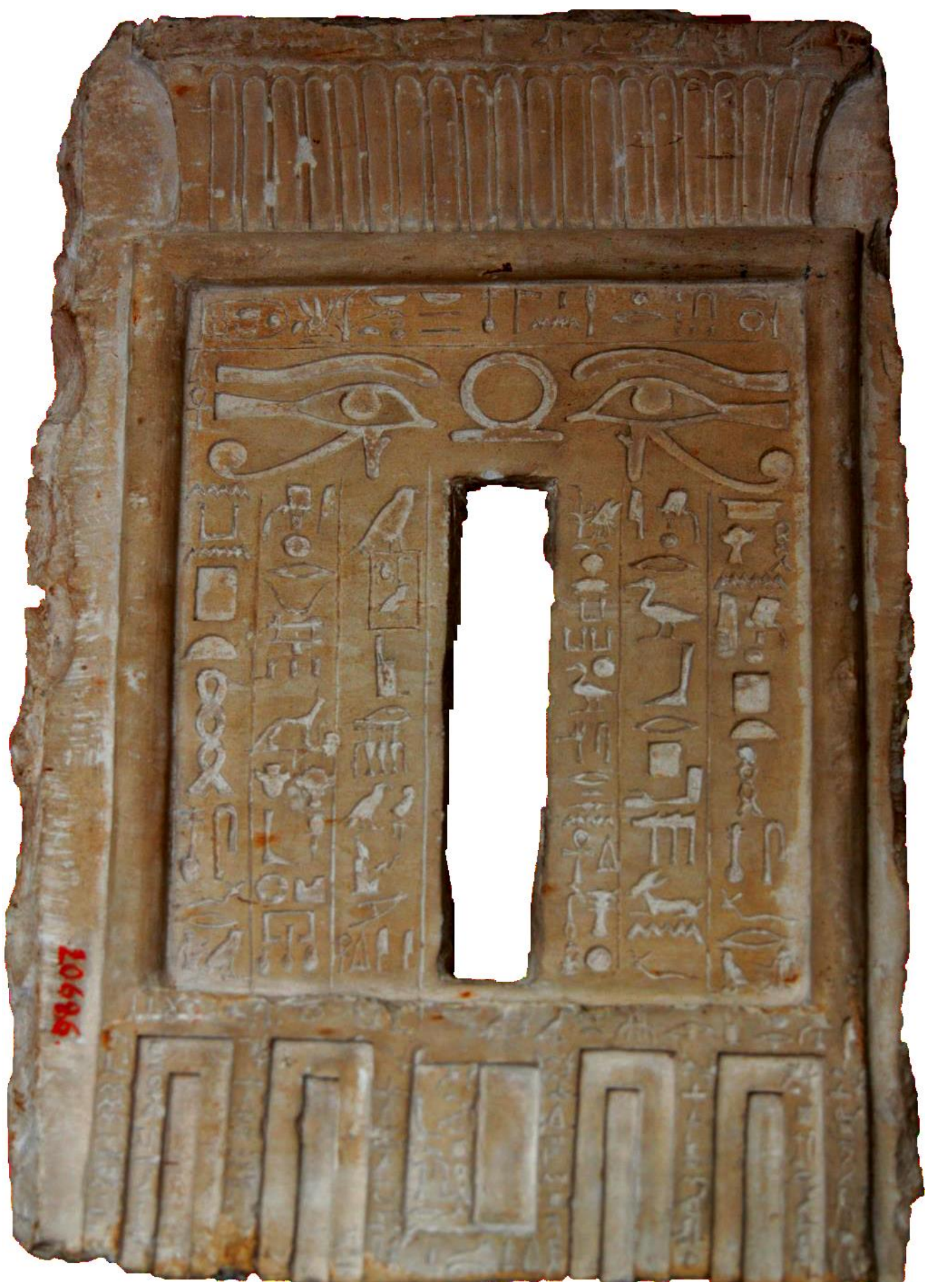

(fig. 2)

(CG 20686=JE 18525=GEM 4109=SR 3/10395). 
i Badawy, A., La Stèle funéraire sous l'Ancien Empire; Son Origine et Son fonctionnement, ASAE 48 (Le Caire 1948), 215.

${ }^{\text {ii }}$ For further information about kom es- sultun, see Ilin- Tomich,A., From Workshop to Sanctuary the Production of Late Middle Kingdom Memorial Stela, MKS 6 (London 2017), 138.

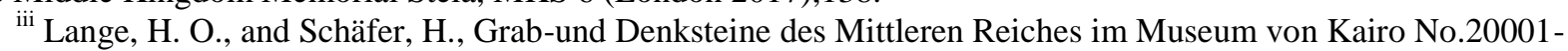

20780, Catalogue Gènèrale des Antiquitès Égyptiennes du Musèe du Caire, I, Texte zu No.2001-20399,(Berlin 1902),217-218; IV, pl. XVI; Grab und Denksteine des Mitteren Reich im Museum von Kairo Nos. 20400-20780, II, 312- 313; IV, pl.LII.

iv Hölzl, R., "Stela", in Oxford Encyclopedia of Ancient Egypt, 3, (Oxford 2001), 319- 324; Martin, K., Stele, in: LÄ, VI (1986), col. 1- 6; Müller, H. W., Die Totendensteine des Mittleren Reiches ,ihre Genesis, ihre Darstellungen und ihre composition, MDAIK4 (1933), 191-201f, fig 20, 21.Vandier, J., Manuel d'archéologie égyptienne, II, (Paris 1954), 416; Evers, H. G., Staat aus dem Stein, I, (Munich 1929),74.

${ }^{v}$ More on the hole/niche inside of the false door stela see Badawy, in: BIFAO 35 (1953), 117- 119, fig.1-7- 9.

${ }^{\text {vi }}$ Kees, H., Horus und séth als Götterpaar, II, (Leipzig 1924), 71- 73; The winged sun disk appeared during the reign of king snefru, where the king's cartridge appeared on the side of the queen's box,Hetebheres at the Egyptian Museum in Cairo, see Badawy, A., La Stèle Funéraire sous L'Ancien Empire: son origine et son Fonctionnement”, 228- 232; the winged sun-disk has appeared on the tops of stelae since the Middle Kingdom, see Wilkinson, R., Reading Egyptian Art,(London 1999),101; In most of the stelae, the individual was not depicted beneath the winged sun disk, but rather depicted kings and deities see Baines, J., The Stela of Emhab: Innovation, Tradition, Hierarchy, JEA 72(1986),52.

vii The cobra was associated with the sun disk and was its protector since the early age, and it kept the path of the sun, but it became a miniature model that is suspended in the sun disk, see Westendorf, W., Der Ring um die Sonnenscheibe, GM 211(2006),115-116.

viii The oldest mention of Osiris is in the Pyramid Texts as the king united with Osiris in the netherworld see Sethe, K., Altägyptische Pyramiden Text, 2 Bde, Leipzig, (1908), 214 (a-c);Osiris took the role of the formerly god of the dead hnty imntt, the god of the netherworld who appeared in the presynaptic period as a couching jackal protecting Abydos necropolis see Saied, M., Götterglauben und Gottheiten in der Vorgeschichte und Frühzeit Ägyptens, Doktorarbeit, Kairo- Uni, (1997), 6-7; LGG, II, 532:568.

${ }^{\text {ix }}$ Gwyn, J., "Osiris", in Oxford Encyclopedia of Ancient Egypt II,(Oxford 2001),615-619;LGG II,527-528; for depicted the god Osiris down the winged solar-disk see CG 20024;AA 41(1984), No.132;Seyfrid,K.J.,in:MAS 15 (1981),247,No.14,CG20542,535.

${ }^{x}$ Romanosky, E., 'Min", in Oxford Encyclopedia of Ancient Egypt II,(Oxford 2001),414; Wilkinson,R.,The complete Gods and Goddesses of Ancient Egypt,(London 2003),115;Mcfarlance,A.,The cult of Min in the third millennium B.C.,BACE (1990),69-75;Mcfarlance,A.,the god Min to the End of the Old Kingdom, (Australian centre for Egyptology 1995),153(nr.312); Barbara, S. Lesko, B., The great goddesses of Egypt, (Oklahoma, United States 1999),15f,81f;Lucas Baqué- Manzano, Further Arguments on the Coptos Colossi, BIFAO 102(2002), 26; Munro, I., Das Zelt- Heiligtum des Min, MÄS 41(1983).

${ }^{x i}$ Ogdon, J., Some Notes on the iconography of the God Min, BES 7,(1985-1986),29-41.

${ }^{x i i}$ For more information on the right raised arm of the god Min see Zandee, J., De Hymnen ann Amon van papyrus Leiden 1,350,(Leiden 1947); Moret, A., Le ritual du culte divin journalier en Egypte. D’aprés les papyrus de Berlin et les textes du temple de Séti $1^{\text {er }}$ á Abydos,(Paris 1902),131;Hassan,S.,Hymnes religieux du Moyen Empire,(Le Caire 1930),141;Junker,H.,Die Onurislegende, Wien 1917(reprint 1988),36.

xiii Concerning the iconographic relation between Min and the flail, it can be said that the flail was a symbol of force and authority, wheras, the flail of Min-Horus in combination with his phallus produces an element of protection and a symbol of his authority against the enemies of the god, see Lichtheim, M., Ancient Egyptian Literature I,(Berkeley 1975),204; It can also be considered the flail as a symbol of fecundity, see Mace, A.C., \& Winlock, H., The tomb of Senebtisi at lisht, Metropolitan Museum of Art Egyptian Expedition,(New York 1916),97;Sourdive,C.,La main dans l'Égypte Pharaonique. Recherches de morphologie structural sur les objets égyptiens comportant une main,(Berne 1984),586.

${ }^{\text {xiv }}$ LGG III,S.293.

${ }^{\mathrm{xv}}$ Barta,W.,Aufbau und Bedeutung der altägyptischen Opferformel,ÄF24,(Glückstadt 1968),56;Lapp,G., Opferformel, Die Opferformel des Alten Reiches ,21(1986), $\$ 155-159,91-110$; wrote in different forms and know since the old kingdom,see Gardiner,A.,Egyptian Grammer,Excursus B,172 ;Barta,W.,Aufbau und Bedeutung der altägyptischen Opferformel,39.

${ }_{\text {xvi }}$ Ranke,H.,Die Ägyptischen Personennamen,1,Verzeichnis der Namen,(Glückstadt 1935),I,79(19). ${ }^{x v i i}$ Ranke,H.,Die Ägyptischen Personennamen,I,280(22).

${ }^{\text {xviii }}$ Satzinger, H., Beobachtungen zur Offerformel: Theorie and Praxis in: LingAeg 5(1997),177-188;Franke,D., The Middle Kingdom Offering Formulas: Achallenge, in:JEA 89(2003), 45- 50; Offering Formula appeared since the

fourth dynasty see Müller, H. W., Die Totendensteine des Mittleren Reiches, ihre Genesis, ihre Darstellungen und ihre composition,185; Translations of this formula have varied, "the king is satisfied and granted" or "A gift offered 
by the king and the god" so in the old kingdom see Barta,W.,Aufbau und Bedeutung der altägyptischen Opferformel,261-270; and in the middle kingdom, the concept changed to become "A gift that the king can give to the god then the god gives it to the deceased" see Gardiner, A., Egyptian Grammar, Excursus B,170173;Leprohon,J.,"The offering formula in the first Intermediate Period" JEA 76 (1990),163-164;Lapp,G.,Die Opferformel des Alten Reiches, $\S \$ 50-52,32-33$.

${ }^{\text {xix }}$ his sequence of epithets ( wsir $n b \underline{d} d w n t r \Upsilon^{3} n b 3 b \underline{d} w$ ) is the most frequent on the Abydos stelae see Barta, W., Aufbau und Bedeutung der altägyptischen Opferformel,56; For the range and frequency of the sequences of epithets on Abydos stelae see Spiegel, J., Die Götter von Abydos (GOF IV.Reihe Agypten7; Wiesbaden 1973), $173-176$. ${ }^{\mathrm{xx}}$ Barta, W., Aufbau und Bedeutung der altägyptischen Opferformel,46ff, for the appearance of di.f after the htp-di$n s w$ formula as an dating cariteria see Obsomer,C., di.f prt ḥrw et la filiation ms(t).n/ir(t).n comme critéres de datation dans les texts du moyen Empire ,dans, in: Ch. Cannuyer/ J.M.Kruchten (eds), Individu, société et spiritualité dans l'Égypte pharaonique et copte :Mélanges égyptologiques offerts au professeur Aristide Théodorides, (Ath/Bruxelles/Mons 1993), 163- 201; satzinger, H., Beobachtungen zur Offerformel:177-188cf; Frank, D., The Good Shepherd Antef(Stela BM EA 1628), in: JEA 93(2007),170-171.

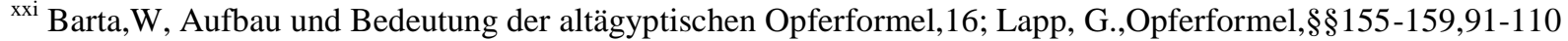
; wrote in different forms and know since the old kingdom, see Gardiner,A.,Excursus B,172 ; Barta,W,Aufbau und Bedeutung der altägyptischen Opferformel ,39; Lapp,G.,Opferformel ,§§155,91.

${ }^{x x i i}$ Ward, W. A., Index of Egyptian Administrative and Religious Titles of the Middle Kingdom, with a clossary of words and phrase used (Beirut1982),87,no.721;Quirke,S.,Titles and Bureaux of Egypt 1850-1700BC, Egyptology I,GHP(London 2004),87; The latter is one of the Titles used predominantly in the Theban and Upper Egyptian administration during the late Middle Kingdom, see Ilin-Tomich, A., Theban Administration in the Late Middle Kingdom, ZAS 142/2(2015),120,128,147; It is attested in large numbers on different monuments dating from the early and mid-Thirteenth dynasty, see Quirke, S., Titles and Bureaux of Egypt,87.

${ }^{x x i i i}$ Franke has noted that on several Second Intermediate Period stelae an additional di,dd was added, spelled

or see Franke, D., The Middle Kingdom Offering Formulas: Achallenge,23-24; these spellings only occur in the Second Intermediate Period. Recently, Marée has shown that most examples belong to an Abydos workshop he has studied see Marée (ed), M., The Second Intermediate Period (Thirteenth -Seventeenth Dynasties):Current Research, Future Prospects, OLA 192(Leuven 2010),pp.250-252.

${ }^{\mathrm{xxiv}}$ For the $h t p-d i-n s w$ formula in general see Barta,W.,Aufbau und Bedeutung der altägyptischen Opferformel,passim; Lapp,G.,Die Opferformel des Alten Reiches, passim .

${ }^{\mathrm{xxv}}$ Müller,H.W.,Die Totendensteine des Mittleren Reiches ,ihre Genesis, 185.

${ }^{x x v i}$ and wrote $h t p$-di-nsw since the age of the Fourteenth Dynasty until the age of the Eighteenth Dynasty and beyond see Smither,PC.,The Writing of htp-d' $i$-nsw in The Middle and New Kingdom ,JEA 25, No.1 (1939),34-37; Bennett, C. J., Growth of htp-di-nsw Formula in the Middle Kingdom, in: JEA 27(1941),77ff; Franke, D., The Good ${ }^{\text {xxvii }}$ Bennett, C. J., Growth of htp-di-nsw Formula in the Middle Kingdom,27-8.

Shepherd Antef (Stela BM EA 1628),39 f.

${ }^{x x v i i i}$ Ilin- Tomich, A., "Changes in the htp-di-nsw Formula in the Late Middle Kingdom and the second Intermediate period", ZAS 138(2011),21,n.13.

${ }_{\text {xxix }}$ Bennett, C. J., Growth of htp-di-nsw Formula in the Middle Kingdom,78.

${ }^{x x x}$ Ilin-Tomich, A., From Workshop to Sanctuary the Production of Late Middle Kingdom Memorial Stela (London 2017), 9; Amgad, J., An Unpublished Stela of Nedjesankh/Iew and His Family (CG 20394/JE 15107), J.ARCE 55(2019),81.

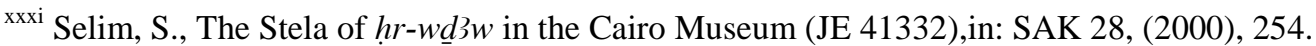

${ }^{x x x i i}$ Abdel- Raziq, A.,A Middle Kingdom funerary stela of a woman at Al-Salam School Museum, Assiut,in: JEA 99(2013), 277.

${ }^{\text {xxxiii }}$ Hein, I\& Satzinger, H., Stelen des Mittleren Riches I, Einschließlich Der 1 und II. Zfiischenzeit,(Mainz, 1989),39-43, 48-54, 56-61.

${ }^{\text {xxxiv }}$ Clère, J., La Stèle de Sânkhptah, chambellan du roi Râhotep ${ }^{\text {,e }}$, in: JEA 68 (1982), 66.

${ }^{\mathrm{xxxv}}$ Orel, S., Two Unpublished Stelae from Beni Hasan ${ }^{e e}$, in: JEA 81,(1995), 218; Bright, D., Dating Funerary Stelae of the Twelfths Dynasty,(Macquarie University 2005), 27.

${ }^{x x x v i}$ Franke,D., The Middle Kingdom Offering Formulas - A Challenge,46; Obsomer, C., di.f prt-hrw et la filiation $m s(t) . n / i ̈ r(t) . n$ comme critères de datation dans les textes du Moyen Empire, 192-196.

xxxvii Azam, L., An Unpublished Stela in the Egyptian Museum, Cairo, JE 88011e, in: CASAE 37(2008), 71;Bennett,C.J.,Growth of the htp-di-nsw formula in the Middle Kingdom ${ }^{\text {ee }}$,77; Lapp, G., Eine spezielle Opferformel des Mittleren Reiches, in: SAK 14,(1987),181-183. xxxviii Ilin- TomichA., "Changes in the Htp-di-nsw Formula",24.

${ }^{x x x i x}$ Bennett, C. J., Growth of htp-di-nsw Formula in the Middle Kingdom,79:81.

${ }^{\mathrm{xl}}$ Barta, W., Aufbau und Bedeutung der altägyptischen Opferformel,33, n.3.

${ }^{x l i}$ Abdalla, A., The Cenotaph of Sekwaskhet Family from Saqqara, in: JEA 78(1992), Fig 2 (b). 
${ }^{x l i i}$ Bennett,C.J.,Growth of htp-di-nsw Formula in the Middle Kingdom,79 (N. 6).

xliii Pflüger,K.,The Private Funuerary stelae of the Middle Kingdom and their importance for the study of Ancient Egyptian History, in: JAOS, vol. 67,No.2(1947),133.

xliv There are several examples on the Thirteenth Dynasty stela mentioned the phrase $n k 3 n$ typically see Cf. Stelae BM EA 215, EA 238, EA 252; Cairo CG 20089. Lapp,G.,Eine spezielle Opferformel des Mittleren Reiches, 182. ${ }^{x l v}$ Ilin-Tomich,A.,"Changes in the Htp-di-nsw Formula",26.

${ }^{\text {xlvi }}$ Whelan, P., An Unfinished late Middle Kingdom Stela from Abydos, in S. Grallert, and W. Grajetzki, Life and Afterlife in Ancient Egypt during rhe Middle Kingdom and Second Intermediate Period, GHP Egyptology 7, (London 2007), 133.

${ }^{\text {xlvii }}$ Ward, W. A., Index MK,no 721;Quirke,S.,Titles and Bureaux,p.87; Quirke,S.,the Regular Titles of the Late Middle Kingdom, in: RdE 37(1986),113,120.

xlviii Ilin- Tomich, A., "Changes in the htp-di-nsw Formula", 23.

${ }^{x l i x}$ Malaise, M., Les representations de divinites sur les steles du Moyen Empire",in:Orientalia J.DuchesneGuillemin emerito oblate,Acta Iranica 23 (Leiden 1984), 408- 411.

'Ilin- Tomich, A., "Changes in the htp-di-nsw Formula",23.

${ }^{\text {li } H e l c k, ~ W ., ~ Z u r ~ V e r w a l t u n g ~ d e s ~ M i t t l e r e n ~ u n d ~ N e u e n ~ R e i c h e s, ~ P A ̈ 3(1958), ~ 51 f f ; ~ G r a j e t z k i, ~ W ., D i e ~ h o ̈ c h s t e n ~}$ Beamten der ägyptischen Zentralverwaltung zur Zeit des Mittleren Reiches,Schriften zur Ägyptologie A2(2000) ,39ff; Quirke,S.,Titles and Bureaux of Egypt,87.

${ }^{\text {lii }}$ Quirke, S., Titles and Bureaux of Egypt, 1.

${ }^{\text {liii }}$ Franke, D.,The Middle Kingdom Offering Formulas,39-40;Smither,P.C.,The Writing of htp-d' Middle and New Kingdom,34-37; Bennett, C. J., Growth of htp-di-nsw Formula in the Middle Kingdom,77-78.

${ }^{\text {liv }}$ Ilin- Tomich, A., From Workshop to Sanctuary, 9; Amgad, J., An Unpublished Stela of Nedjesankh/Iew and His Family (CG 20394/JE 15107),81.

${ }^{\text {lv }}$ Obsomer, C., di.f prt hrw et la filiation $\mathrm{ms}(\mathrm{t}) . \mathrm{n} / \mathrm{ir}(\mathrm{t}) . \mathrm{n}$ comme critéres de datation dans les texts, 198 .

${ }^{\text {lvi }}$ Pflüger, K., The Private Funuerary stelae of the Middle Kingdom and their importance for the study of Ancient Egyptian History,133;EL- Sayed, M.,Late Middle Kingdom stelae from Assiut, in: H. W. Fischer-Elfert \& R. B. (eds.)Parkinson,Studies on the Middle Kingdom in Memory of D.Franke, PHILIPPIKA 41 , (Wiesbaden 2013),161 199; it sometimes replaces the sign ${ }^{h}$ (S3) instead of the sign ${ }^{m}$ (N35) from the Twelfth Dynasty and recurrently at the end of the Middle Kingdom, see Obsomer,C.,Égyptien Hièroglyphique. Grammaire pratique du Moyen ègyptien,Cllection Langues et Cultures anciennes 11(2009),239.

lvii Ilin-TomichA.,"Changes in the htp-di-nsw Formula”,26;Ilin-Tomich,A.,Middle Kingdom Stelae Workshop at Thebes, in: GM 234(2012),80;EL-Shal,O.,La stèle d'Ioutjèni et les liturgies processionnelles de la fin du Moyen Empire CGC 20476,GEM 4439,in BIFAO 115 (2015),462.

Iviii Ilin- Tomich, A., "Changes in the htp-di-nsw Formula",23.

${ }^{\text {lix }}$ Müller,H.W.,Die Totendensteine des Mittleren Reiches ,ihre Genesis,191-201,fig.20-21;J.Vandier,Manuel

d'archéologie égyptienne,II,(Paris 1954), 416;Evers,H.G.,Staat aus dem Stein,I,(Munich 1929),74.

${ }^{1 x}$ Hölzl, R., "Round-Topped Stelae from the Middle Kingdom to the Late Period,Remarks on the Decoration of the Lunettes", SCIE I (1992),287; Hölzl,R.,Die Giebelfeiddekoration von Stelen des Mittleren Reich, (Wien 1990),48-

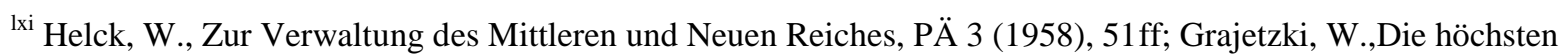
50.

Beamten der ägyptischen Zentralverwaltung zur Zeit des Mittleren Reiches,Schriften zur Ägyptologie A2(2000) ,39ff;Quirke,S.,Titles and Bureaux of Egypt,p.87.

lxii Haeny,G., 'Scheintür', in $L \ddot{A}$ V,(Wiesbaden 1984),564, fig. 2.

lxiii Pflüger, K., The Private Stelae of the Middle Kingdom and Their Importance for the Study of Ancient Egyptian History, 128.

${ }^{\text {lxiv }}$ The Hory of king Senwosert III.

${ }^{\mathrm{lxv}}$ Title of the god Osiris, see LGG II, 528- 534.

${ }^{\text {lxvi }}$ Title of the coronation of king Senwosert III

lxvii Goodwin, C. W., "On the Symbolic Eye Uta", ZÄS 10 (Berlin1872), 124; Wilkinson,R.,Reading Egyptian Art, (London1992), 43; Two udjat eyes appeared since the Old Kingdom on the fake doors, during the Middle Kingdom, It appeared on coffins see Stadelmann, R., " Places ", in: OEAE, III (Oxford 2001),15; Moret, A., "Serdab et Maison du Ka ",ZÄS 52 (Berlin1914), 89; Hart, G., A Dictionary of Egyptian Gods and Goddesses, (London 1986), 73; in order for the deceased to fulfill his wish by seeing the light of day see Tawfik, S. , "A $w^{c} b$ Priest Stela from

Heliopolis", GM 29 (1978),133, while the udjat eyes appeared on stelae since the Twelfth Dynasty, for protection and ward off evil, bring good luck, cure and health, and the deceased can look at those who offer him offerings, Two eyes symbolizing the entombed deceased who, through it, can always have a connection with our world see Tawfik, S., "A w`b Priest Stela from Heliopolis ,133; Radwan, A., The Stela louvre C211,107; in the New Kingdom, the two udjat eyes is depicted, and two wings are added to it, which fly behind the king and the gods, try to cast protection shadows on them see Wilkinson, R., Reading Egyptian,43; and in the Late period, two udjat eyes fell depicted at the top of the stelae, and the winged sun disk became the predominance of the top decoration, which became more 
widespread until the Ptolemaic period see Hölzl, R., "Round-Topped Stelae from the Middle Kingdom to the Late Period",287.

lxviii Hölzl, R., Die Giebelfelddekoration von stelen des mittleren Reiches, 111.cf.also Fischer, H. G., Archaeological Aspeets of Epigraphy and palaeograpgy, in: Caminos, R. A.\&Fischer, H. G., (eds), Ancient Egyptian Epigraphy and palaeography, (New York 1976), 46-47;A sign appeared $\check{s} n$ surrounded by two eyes $w d \underline{d} t$ at the tops of the stelae since the end of the Twelfth Dynasty see Robins, G., The Art of Ancient Egypt,(London 1997),204; symboliz the sign $\check{s} n$ to life, resurrection, renewal and protection, it is a symbol of the universe as it consists of the sun disk representing the world of the sky and the base that represents the earth and the underworld, therefore, the $\check{s} n$ sign was depicted on the stelae to ensure the deceased was supplied with offerings in the other world see Hölzl, R.,

"Round-Topped Stelae from the Middle Kingdom to the Late Period,287.

Ixix This word appeared with different forms as see: LDD, V,783. the common form during the Thirteenth Dynasty is I\& Satzinger, H., Stelen des Mittleren Riches I, Einschließlich Der 1 und II. Zfiischenzeit, Mainz, (1989). ${ }^{1 \times x}$ A resident guest in another temple see Badawi,A.\&Kess,H.,Hand Woerterbuch,(Kairo,Staatsdruckerei 1958), 163.

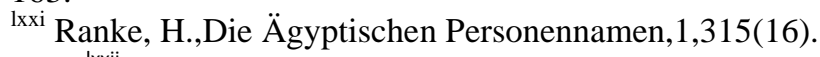

Ixxii was a funerary deity For Wpwawt, see Eissa, A.,Untersuchungen zum Gott Upuaut his zum Ende des Neuen

Reiches, unpublished PhD,(Cairo Uni 1989),passim; and one of the earliest gods worshipped at Abydos. Starting with the $12^{\text {th }}$ dynasty, he became the main deity of Abydos and gained, the epithets "Lord of Abydos" and "Lord of the Necropolis" see Morenz, S., Egyptian Religion, translated by A. E. Kemp,(Cornell University press 1992),173; Houser-Wecner,J.,in:Oxford Encyclopedia of Ancient Egypt.III (2001),96-97.

lxxiii The artist made a mistake here and wrote a sign- ${ }^{\prime} n h$ before sign- $d i$.

lxxiv The artist made a mistake and made a sign-nfr before sign-s .

${ }^{\mathrm{lxxv}}$ Another form of writing the name see Ranke, H., Die Ägyptischen Personennamen,1,315(16).

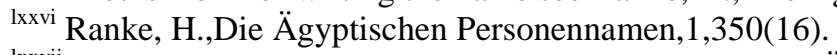

lxxvii Another form of writing the name see Ranke, H., Die Ägyptischen Personennamen,1,315(16).

lxxviii This word appeared in the middle Kingdom see Wb II,339.

lxxix Another form of writing the name see Ranke, H., Die Ägyptischen Personennamen,1,315(16).

${ }^{1 x x x}$ This name was not mentioned by Ranke, H., Die Ägyptischen Personennamen, I.

lxxxi CG20014, CG20231, CG20393, CG20435, CG20528, CG20686, CG20715.

lxxxii Evers, H. G, Staat aus dem Stein,II,(Munich 1929),566.

lxxxiii Franke, D., The Middle Kingdom Offering Formulas,39-40;P.C.Smither, The Writing of htp-di-nsw in the Middle and New Kingdoms, 34-37; C. J. Bennett, "Growth of the Htp-di-nsw Formula in the Middle Kingdom”, 7778.

${ }^{\text {lxxxiv }}$ Smither, P. C., The Writing of htp-di-nsw in the Middle and New Kingdoms,34-37;Urk.VII,43,6;54,2; Barta, W., Aufbau und Bedeutung der altägyptischen Opferformel, 53, 72; Budge, W., Hieroglyphic texts from Egyptian Stelae in the British Museum, I,(London 1911),pls.48,53-54;Budge,W.,Hieroglyphic texts from Egyptian Stelae in the British Museum, II,(London 1912),pls.2-5,10-17, 19,20, 22,25,27-31,34-36,38-39,44 ;Blackman, A. M., Some Middle Kingdom Religious Texts, in: ZÄS 47 (Berlin 1910) ,116; Fischer, G. H., Egyptian Studies III, Varia Nova, (New York 1996), 134, pl. 21; 135, pl.33a; 139, pl.26; Simposon, W. K., The Terrace of the Great God at Abydos ; The Offering Chapels of Dynasty 12 and 13,Publications of the Pennsylvania-Yale Expedition to Egypt 5, (Philadeiphia 1974), pl.24.ANOC 14.1,CCG 20043,ANOC 15.1,CCG 20055; pl.25,ANOC 16.2,CCG 20240; pl.46,ANOC 30.1,CCG 20515; Saleh, M., Official Cataloque. The Egyptian Museum Cairo, (Mainz 1987) ,9192;Spanel,D.B., Paleographic and Epigraphic Distinctions between Texts of the So-called first Intermediate Period and the Early Twelfth Dynasty, in Der Manuelian p.,(ed.),Studies in Honour of William Kelly Simpson , II,(Boston 1996),780-781,fig 4-5;Franke, D., Drei neue Stelen des Mitteren Reiches von Elephantine, in: MDAIK 57

(Wiesbaden 2001),26,Abb.4;Bazin,L.,\&EL-Enany, Kh., La stèle d'un chancelier du roi et prophète d'Amon de la fin du Moyen Empire á Karnak,in Cahiers de Karnak 13(2010), 2-3,figs.1-2;EL-Enany,Kh.,Une stèle privèe de la fin du Moyen Empire dècouverte á karnak. Le Caire, Musèe ègyptien JE 37515, in: BIFAO 108 (Le Caire 2008), 96-97; this arrangement was also common in the first Intermediate Period see Fischer, H. G., the Nubian Mercenaries of Geldein during the First Intermediate Period, in: Kush 9 (Khartoum 1961),47, fig.1; 57,fig.3; 60 , fig.4 ; Kubisch, S., Die Stelen der 1.Zwischen Zeit aus Gebelin, in: MDAIK 56 (Wiesbaden,2000), 250.

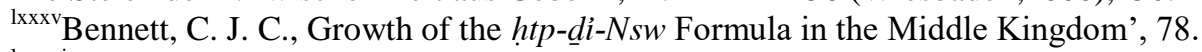

${ }^{\text {lxxxvi }}$ Urk. VII, 8, 6, 18; 9, 2; 11, 11; 20, 7; 21, 15;22, 13, 20;23, 15;24, 7; 28, 8, 19; 32, 4; 33, 4; 34, 7; 35, 15. 